
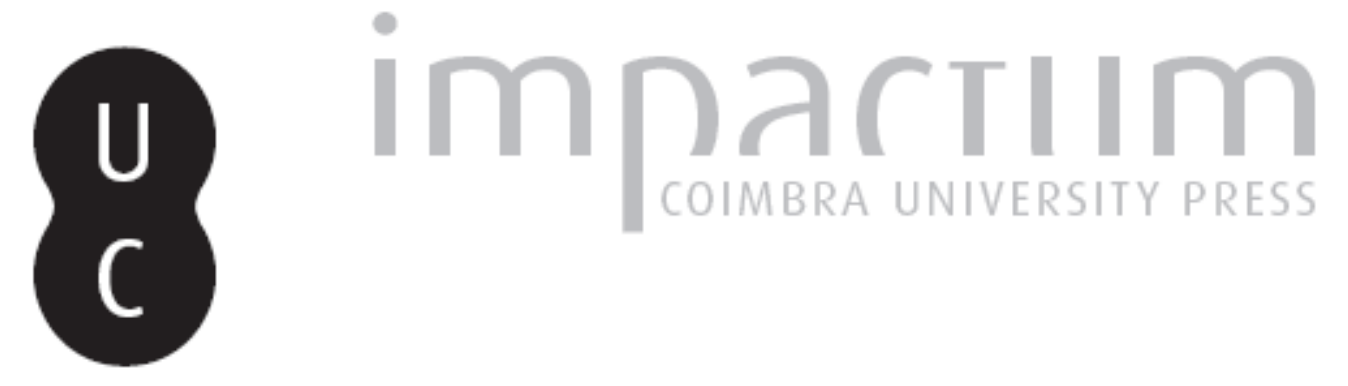

\title{
Pulchritudo and ornamentum, naked beauty and ornamental beauty: the legacy of Leon Battista Alberti
}

Autor(es): $\quad$ Loewen, Andrea Buchidid

Publicado por: Editorial do Departamento de Arquitetura

URL persistente:

URI:http://hdl.handle.net/10316.2/37243

DOI:

DOI:http://dx.doi.org/10.14195/1647-8681_5_15

Accessed : $\quad$ 26-Apr-2023 08:23:06

A navegação consulta e descarregamento dos títulos inseridos nas Bibliotecas Digitais UC Digitalis, UC Pombalina e UC Impactum, pressupõem a aceitação plena e sem reservas dos Termos e Condições de Uso destas Bibliotecas Digitais, disponíveis em https://digitalis.uc.pt/pt-pt/termos.

Conforme exposto nos referidos Termos e Condições de Uso, o descarregamento de títulos de acesso restrito requer uma licença válida de autorização devendo o utilizador aceder ao(s) documento(s) a partir de um endereço de IP da instituição detentora da supramencionada licença.

Ao utilizador é apenas permitido o descarregamento para uso pessoal, pelo que o emprego do(s) título(s) descarregado(s) para outro fim, designadamente comercial, carece de autorização do respetivo autor ou editor da obra.

Na medida em que todas as obras da UC Digitalis se encontram protegidas pelo Código do Direito de Autor e Direitos Conexos e demais legislação aplicável, toda a cópia, parcial ou total, deste documento, nos casos em que é legalmente admitida, deverá conter ou fazer-se acompanhar por este aviso.

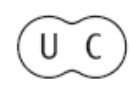




\section{Andrea Buchidid Loewen}

\section{Pulchritudo and ornamentum,}

naked beauty and ornamental beauty:

the legacy of L,eon Battista Allberti

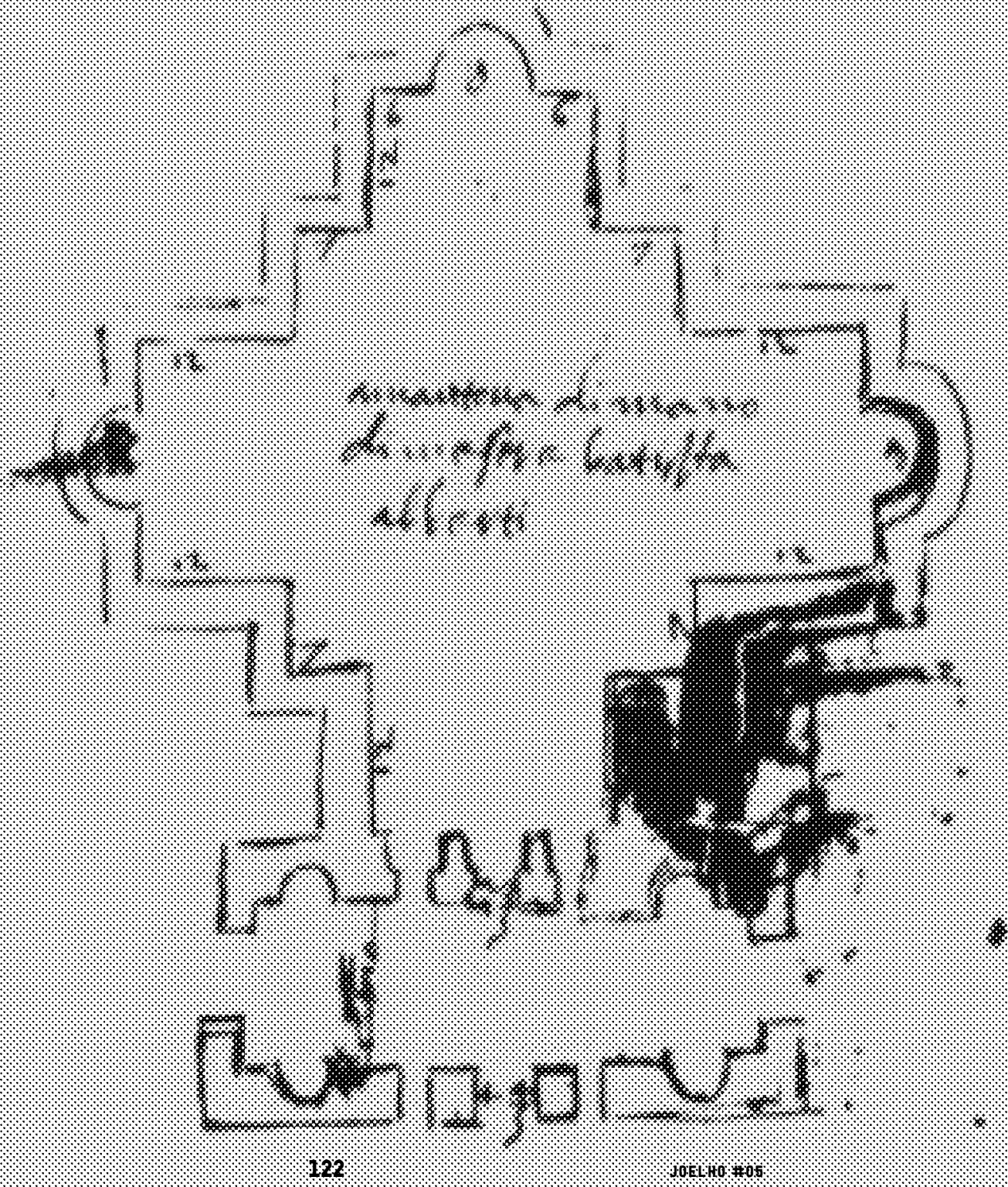


Alberti's treatises on Painting and on Architecture were without any doubt the most significant contribution to the doctrines of these Arts in the fifteenth century. In both of them significant attention is given to the matters of beauty. In the De Pictura, dating from 1435, Alberti begins to cast his principles on beauty and ornament. Painting is the mistress of all the arts and their principal ornament, he declares at the beginning of the second book (Alberti, 1972, II, p. 61), further adding that from painting derives whatever beauty there is in things: the architect took from the painter architraves, capitals, bases, columns and pediments, and all the other fine features of buildings.

But although Alberti indicates in this work how to achieve beauty (pulchritudo) and repeatedly refers to it and its synonyms (venustas, concinnitas, gratia, decoris, leporis, formosum), a definition of beauty is not thoroughly given. A greater precision of the notion of pulchritudo is developed in his treatise on Architecture. In the sixth book, after asserting that the precise nature of beauty and ornament, and also the difference between them, is more clearly visualized in the mind than his words could explain, Alberti (1988, VI, 2, p. 156) defines beauty as that reasoned harmony of all the parts within a body, so that nothing may be added, taken away, or altered, but for the worse. However, he also distinguishes a form of auxiliary light and complement to beauty: ornamentum.

The distinction between an inherent beauty and an attached one, arising from additions, is indebted to the Rhetoric. Under the guidance of Cicero and Quintilian, Alberti defines the ornament as the realm of the particular. As in Oratory, in Architecture ornament is the great instrument to differentiate the types and parts that identify the various buildings; it corrects and enhances its forms and offers them character, presence and dignity.

From Rhetoric, Alberti (1988, IX, 10, p. 315) takes over the principle of decorum, appropriateness, and states that the greatest glory in the art of building is to have a good sense of what is appropriate. It is a parameter that guides beauty and regulates the ornaments, the visible aspect of virtù, the regulator of temperance and moderation, and as such not only it is perceived by means of reason, but it is also a quality that stands out.

Thus, in view of decorum, convenience, Alberti prescribes the ornaments appropriate to each building type and each situation. For the private buildings in general he designates a very restrained architecture, but also one that may appeal to greater freedom in the details. However, although such buildings cannot conform to the same rules used in public buildings, they may never become ugly or decayed: they may tend to iocunditas (joy, pleasure), while public works must meet the gravitas and the letters of the law. As for the sacred buildings, the temples, Alberti recommends that those dedicated to gods should be ornamented with gravitas and the ones dedicated to goddesses with venustas (LOEWEN, A. B., 2012, p. 135). The convenience of such an expression of character refers to Vitruvius' De Architectura, particularly
1. Antonio Labacco. Annotated plan and sketch elevation of San Sebastiano in Mantua. Florence, Galleria degli Uffizzi, Gabinetto Disegni e Stampe 1779A 


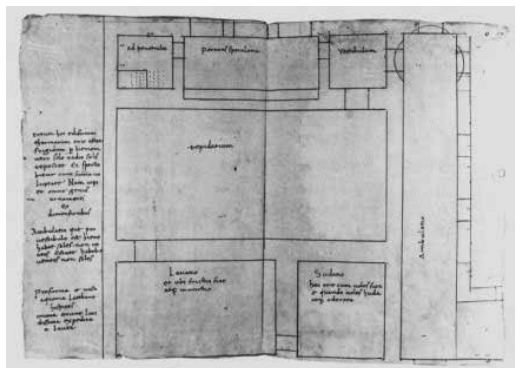

2. Alberti (attrib.) Drawing for a bath building.

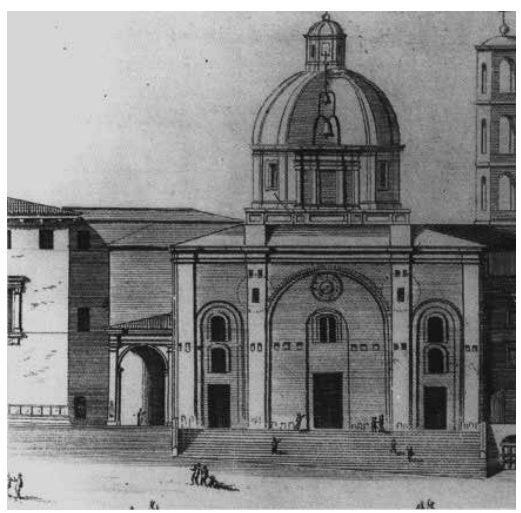

3. The facade and dome of the Duomo di Urbino. Detail from the 1724 Baldi-Bianchini's incision. with regard to the reiteration of the use of Doric colonnades to the deities of severe character and Corinthian colonnades for those of delicate character.

In fact, the coincidence between the idea of ornament and that of architectural order is expressed for the first time in the De Re aedificatoria. Alberti (1988, VI, 13, p. 183) states that in the whole art of building the column is the principal ornament without any doubt, clarifying later that the columnar patterns comprise the following: the pedestal and, on top of that, the base; on the base, the column, followed by the capital, then the beam, and on top of the beam, the rafters, their cut-off ends either terminated or concealed by the frieze; finally, at the very top comes the cornice (Idem, VII, 6, p. 200). The author advises, however, that such considerations are not a discovery by the ancients, handed down in some writing, but what we have noted ourselves, by careful and studious observations of the works of the best architects (Idem ibidem, VI, 13, p. 188).

Ornament is regarded as a necessary overlay to any well-defined building, for it has the effect of making the displeasing less offensive and the pleasing more delightful (Alberti, 1988, VI, 2, p. 156). The importance given to this issue is such that, in order to advise on the flaws to be avoided during the construction and ornamentation of buildings, Alberti (1988, IX, 8, p. 312) suggests that the work ought to be constructed naked, and clothed later; let the ornament come last. Robert Tavernor (1994, p. 305) has taken such recommendation as a precaution, since the election of the ornaments requires some thought and therefore there should be an interval between the two operations. He asseverates, however, that a state of undress is intended to be temporary, especially for public and sacred works: since no man would allow them to be naked of ornament (Alberti, 1988, IX, 8, p. 312).

For the scholar, an evidence of this Albertian principle according to which a building should be outlined naked of any ornament is found in Labacco's drawing - di mano di messere batista alberti-, of the church of San Sebastiano in Mantua as well as in an annotated plan of a thermal building to be constructed in Urbino attributed to Alberti. Both designs are drawn very schematically: columns and pilasters are not indicated, and probably the ornament's project would have been drawn from this intrinsic beauty (Tavernor, 1994, p. 305).

The appreciation of a kind of beauty inherent to the structure of edifices finds peculiar resonances still during the Renaissance, as seen in the works of Francesco di Giorgio Martini. In the writing dedicated to Martini's churches, Manfredo Tafuri (1993, p. 21) has analyzed the Duomo of Urbino. Not only has he shown the Albertian characteristics of the work but also pointed out the absolute nudity that pervades the whole building: with some sort of obsession, the organism is put in evidence; vaults and arcades seem not to support 'adjoining beauties'.

According to this author, the prevailing feature of the church is the utter lack of architectural orders: both the pillars that divide the 
nave and the walls - excavated by niches in the aisles-are displayed with an almost hallucinated purism (Tafuri, 1993, p. 21). Among the possible sources of the architect, ancient monuments that Francesco may have studied before his arrival in Urbino in 1477 or even earlier, are buildings that renounce the orders or decoration to display their very expressiveness. The Baths of Caracalla, the nicchioni di Todi or the Arch of Augustus in Fano are all works that praise the structure, the relationship between arch and support and the continuity of the walls.

Christoffer Ericsson (1980, p. 12) has argued that Roman public and monumental architecture from the fourth and fifth centuries was the ancient architecture that survived in better conditions, and thus was studied by Francesco di Giorgio, as well as early Christian architecture: it was this which was considered typically Roman. Still, as Tafuri (1993, p. 24) recalls, foglio $72 \mathrm{r}$ of the codex Saluzziano shows two ancient buildings that can be related to the Duomo as conceived by Martini: the theater of Gubbio, for its pillars swept by entablatures and cornices; and the theater of Ferento, for the absolute lack of the orders. What matters to the issue is that these are monuments whose rhetoric denies the visual hedonism of the adorned Antiquity; that choice certainly led Francesco di Giorgio to Alberti.

Tafuri (1993, pp. 24-25) convincingly defends that Francesco's inventions owe a lot to Alberti. The arches on pillars that define the tripartite nave of the Duomo recall the sides of the Malatesta Temple in Rimini and the Duomo's grand barrel vault, boldly built without buttresses, is one of the first structural experiences of such kind in the fifteenth century, after the Abadia fiesolana and the Albertian model for Sant 'Andrea in Mantua. Given the close relationship between the courts of Mantua and Urbino, the scholar assumes that Martini may have known, if not the model itself, at least drawings of the temple.

Although the affinities between the two architects cannot be attributed to a direct reading of the Latin text of the De re aedificatoria, it can be assumed that Alberti's ideas were known to the humanists in the intellectual world of Urbino, which Martini frequented on and off between 1477 and 1490. In addition to the testimony of his works, Francesco's treatise also shows some assimilations of the Albertian notion of inner beauty. In the chapter on temples he argues that the sacred temples must be made of the most varied and diverse forms according to the invention, subtlety and talent (ingegno) of the architect, always respecting the measurements and proportions belonging to them, which are all derived from the human body (Martini, 1967, vol. I, p. 36).

However, unlike Alberti's, Francesco's writing on architecture was never published; nonetheless, his manuscripts were known in most circles and circulated in various forms throughout the Italian peninsula and beyond (See Payne, 1999, pp. 89-90 and Onians, 1988, p. 171).

If an essentially theoretical character prevails in the treatises of the fifteenth century, by the Cinquecento a much more practical address is asserted concerning the main purpose of resolving

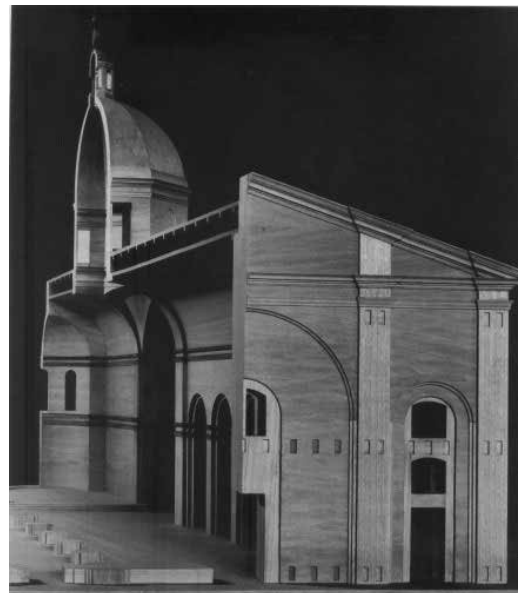

4. Model of the Duomo according to Francesco di Giorgio's project. Model by Grazia Sgrilli and Manfredo Tafuri. Photo Sgrilli.

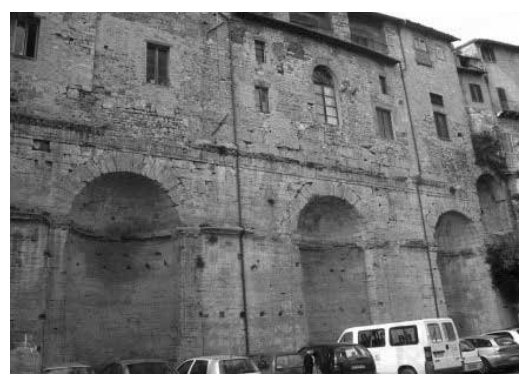

5. The Nicchioni. Todi. Photo Fantasy.

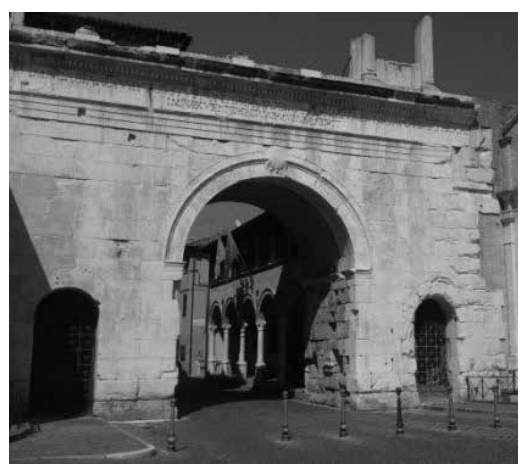

6. Arco di Augusto. Fano. Photo Parsifall. 


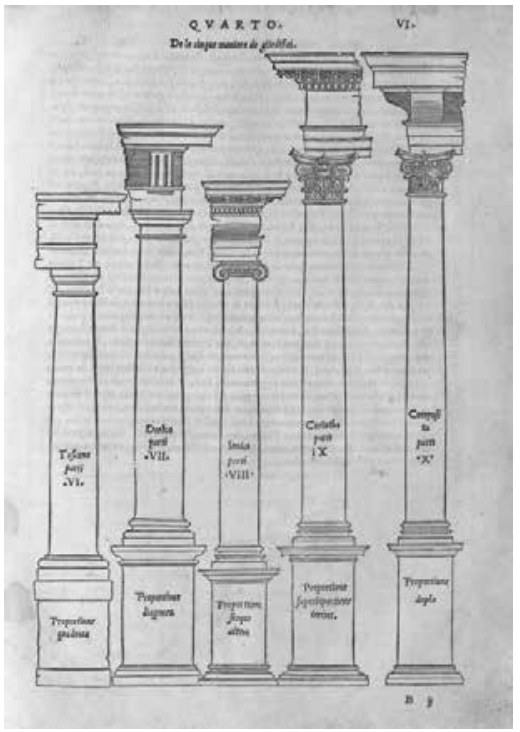

7. Serlio. Book IV, 1537. Plate of the Five Orders.

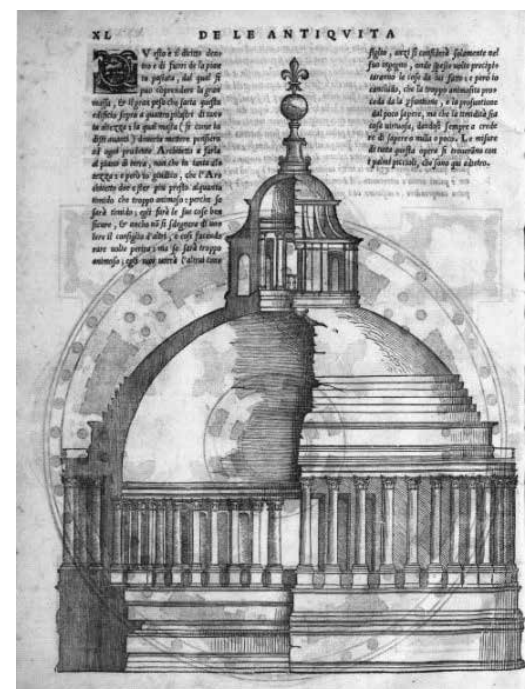

8. Serlio. Book III, 1540. Bramante's project for St Peter's dome. the much-debated issue of the architectural orders and representing the ancient monuments with the intention of reconstituting the obscurity of the Vitruvian text.

Despite the significant change in character, the treatises of the sixteenth century may lead to Alberti as undoubtedly albertian is the idea of order as adherent ornament which Serlio and Vignola share with their masters and contemporaries and around which much of the architectural debate since the fifteenth century has focused. As Alina Payne (1999, p. 75) has noted, without Alberti's definition of ornament, later books such as Serlio's or Vignola's would be incomprehensible.

The first major treatise of the Cinquecento was Sebastiano Serlio's book on the orders of 1537. It was published in Venice as Book IV and under the title of Regole generale d'architettura sopra le cinque maniere degli edifici, cio é thoscano, dorico, ionico, corinthio et composito, con gli esempi dell'antiquita, che, per la maggior parte concordano con la dottrina di Vitruvio and preceded Il terzo libro di Sebastiano Serlio Bolognese, nel quale si figurano, e descrivono le antichità di Roma, e le altre che sono in Italia, e fuori d'Italia, published also in Venice in 1540.

In his justification to the readers explaining why he had started publishing the seven books of his treatise by Book IV, Serlio explains that it was più a propósito, \& più necessario deglialtri per la cognition delle differenti maniere degli edificij, \& de' loro ornamenti (Serlio, 1566, IV, p. 126). Both Books III and IV are concerned with antiquity and its uses and place great emphasis on the matter of ornament.

It is also important to consider when those books were published, for little had been written or even printed since Francesco di Giorgio's death. Those were years of intense architectural activity and thorough investigation and survey of the reminiscences of antiquityas Raphael's letter to Pope Leo X, Sangallo's work on Vitruvius and the antiquities of Rome, and the many editions and exegesis of the De architectura libri decem all witness.

In such context, it is relevant that Serlio's book on antiquities contains modern architecture too, some examples of what, in his point of view, interpreted better than any other the line of architectural renovation that took place in Rome at the beginning of the sixteenth century-Bramante's projects for Saint Peter's dome, for the Vatican Belvedere with its monumental exedra, for the Tempietto with the unexecuted project for the reform of the courtyard, and Peruzzi's and Raphael's projects for the construction of the new Saint Peter's. Thus, it can be argued that this new genre developed by Serlio begins with the path inaugurated by Bramante in Rome and shows continuity not only with the investigations of Peruzzi, but also with all the architects that worked in the city during those years.

Like Bramante, Serlio did not follow Vitruvius or the regole dogmatically. In addition to the interpretations proposed by Raphael and Antonio da Sangallo, his training as a painter led him to particularly appreciate the use of the orders to give rhythm to the walls. So, by 
that time ornament was not only the most visible and eloquent sign of appropriation of antiquity, but it had also become the most immediate means to manifest the architect's ingegno.

As Alina Payne has argued (1999, p. 115), Serlio's books stands testimony to the fact that by the third decade of the sixteenth century ornament elucidated a discourse all its own. Where Alberti had offered a textual precedent in devoting one-half of his treatise to ornament, Serlio went one step further and combined text with the visual instrument, declaring ornament to be an independent and central concern, complex and important enough to claim the space of a full treatise.

Under this perspective, it can be argued that Serlio's Book IV corresponds to a treatise on ornament and the same line of thought applies to Vignola's Regole delli Cinque Ordine d'Architettura, first published in 1562 .

The ease of understanding of this treatise derives from the method formulated by the author which aims to regulate the use of the classical ornatus. In fact, Vignola does not present the orders as they result from the observation or the survey of individual monuments, but recomposed according to a mathematical system, conceived by him, that allows the definition of a precise concert of relations among the various parts that compose the building (Loewen \& Azevedo, 2010, p. 14).

Given the uncertainties that pervade the post-Tridentine times, the criticism addressed to the more ornamental parts of architecture, and considering the varieties and divergences in alternatives observed in Vitruvius' text, in the ancient monuments, and in the interpretations of the architects of the circle of Bramante, Vignola rejects idiosyncratic choices and affirms the need to be endorsed in certainties. In the brief preface to the Regola he declares: having for many years, in many places, exercised this art of Architecture, I was often pleased, concerning this practice of the ornaments, to see the opinion of as many writers as there are, and comparing them with each other and with the ancient works, I tried to extract a rule in which to appease with the security (Vignola, 1635, p. II).

That's why among the ancient ornaments of the five orders which were seen in the antiquities of Rome, he selects those which to the common judgment, appear more beautiful and gracile to our eyes (Idem, p. II). From the many models suggested by the ancients and freely interpreted by the architects of the preceding generation, he defines the only model, elevated to the stature of canon: archetype cunningly extracted from an Antiquity ideal, abstract, timeless and, thus, reinvented and reduced to a unifying rule (Loewen \& Azevedo, 2010, p. 14).

With this work, Vignola intended to offer his readers the only measure of the beautiful and the correct. The clarity and ease of use of this treatise caused it to become the most published book in architectural history in succeeding centuries.

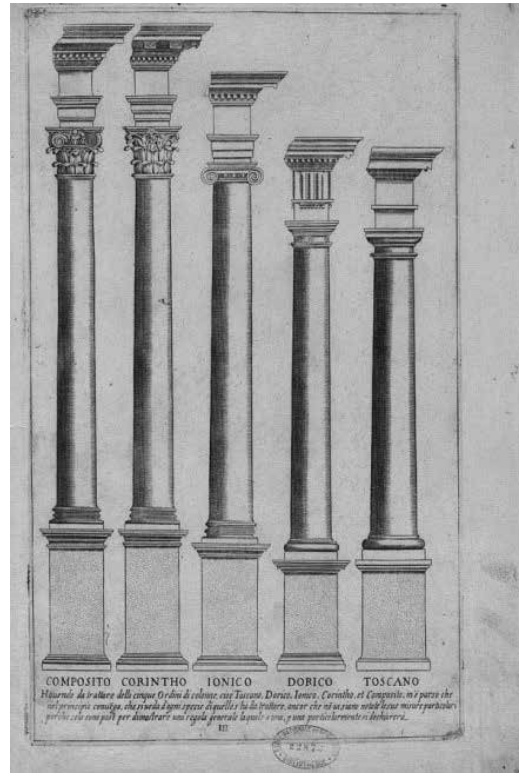

9. Vignola. Regola, 1562. Roma. 


\section{References}

ALBERTI, L. B. (1988). On the Art of Building in Ten Books (Trad. J. Rykwert, N. Leach, R. Tavernor). Cambridge: MIT Press.

\section{(1972). On Painting and}

On Sculpture - the Latin Texts of De Pictura and De Statua (Edited with translations, introduction and notes by Cecil Grayson). London: Phaidon Press.

ERICSSON, Christoffer H. (1980).

Roman Architecture expressed in sketches by

Francesco di Giorgio Martini. Helsinki:

Societas Scientiarum Fennica.

LOEWEN, A. B. (2012). Lux pulchritudinis: sobre beleza e ornamento em Leon Battista Alberti. São Paulo: Annablume.

LOEWEN, A. B. \& AZEVEDO, R. M. de. (2010). A doutrina de Giacomo Barozzi da Vignola. In ABREU e LIMA, F. \& MIGLIACCIO, L. (orgs.) Regra, Ordem, Invenção. Modelos de Arquitetura da Biblioteca de John Graz. São Paulo: FAUUSP, 2010.
MARTINI, Francesco di Giorgio. (1967). Trattati di architettura, ingegneria e arte militare. Edizione, introduzione Corrado Maltese e Livia Degrassi Maltese. Milano: II Polifilo, 2 vols.

PAYNE, Alina A. (1999). The Architectural Treatise in the Italian Renaissance. Architectural Invention, Ornament and Literary Culture. Cambridge/New York: Cambridge University Press.

SERLIO, Sebastiano. (1566). Libro Primo [-quinto] d'Architettura di Sebastiano Serlio Bolognese. Venetia: Appresso Francesco Senese \& Zuane Krugher Alemanno, Compagni.

TAFURI, Manfredo. (1993). "Le chiese di Francesco di Giorgio Martini". In FIORE, Francesco Paolo e TAFURI, Manfredo (a cura di). Francesco di Giorgio architetto. Milano: Electa.

TAVERNOR, Robert. (1998). On Alberti and the Art of Building. New Haven and London: The Yale University Press.
(2004). "Concinnitas, o la formulazione della bellezza". In AAVV Leon Battista Alberti - a cura di J. Rykwert e A Engel. Op. cit, pp. 300-315.

VIGNOLA. (1635) Regola delli Cinque Ordini D'architettura di M. Iacomo Barozzio Da Vignola. Siena, 1635. 